Reprod. Nutr. Dévelop., 1986, 26 (2 A), 461-474.

\title{
Stages of oogenesis in the snail, Helix aspersa : cytological, cytochemical and ultrastructural studies
}

\author{
Bernadette GRIFFOND, Danielle BOLZONI-SUNGUR \\ Laboratoire de Zoologie et Embryologie, \\ UA CNRS, $n^{\circ}$ 040687, Université de Franche-Comté, \\ Faculté des Sciences, place Maréchal.Leclerc, \\ 25030 Besançon cedex, France.
}

Summary. Oogenesis was studied in adult Helix aspersa using light and electron microscopy. The development of the female germ cells was divided into six stages based on morphological, cytochemical and ultrastructural criteria. The abundance and localization of cytoplasmic organelles, nuclear and nucleolar changes and the successive appearance of reserve substances during these stages have been described as well as the structural relations between oocytes and follicle cells.

\section{Introduction.}

Oogenesis inside molluscs is characterized by a certain uniformity /Guyard, 1971); however, some important, specific variations occur, for example, in oocyte size, nucleolar activity, the nature and origin of yolk substances. Very little data exist on the Helicidae, apart from old or incomplete descriptions (Rogers Brambell, 1924 ; Serra and Queiroz Lopez, 1945 ; Ranzoli, 1957 ; Guyard, 1971). While conducting an experimental investigation of the control of oogenesis by the central nervous system and the dorsal bodies (Vincent et al., 1984), we recently reexamined oogenesis in Helix aspersa. The aim of the present work was to determine by some precise criteria the different stages of oogenesis in this species in order to define morphological references for subsequent studies.

\section{Material and methods.}

Animals. - Adult snails bred in the laboratory under controlled conditions were used (temperature : $20^{\circ} \mathrm{C}$; humidity : saturation; food: Sanders (1). Their gonads presented various stages in the development of the female germ cells. Electron microscopy. - The ovotestes were fixed for $2 \mathrm{~h}$ at $4{ }^{\circ} \mathrm{C}$ in a mixture of

(1) Sanders, 17, quai de l'industrie, 91200 Athis Mons. 
$2 \%$ glutaraldehyde, $0.1 \mathrm{M}$ sodium cacodylate, $0.17 \mathrm{M} \mathrm{NaCl}(1: 1: 1)$ ( $\mathrm{PO}=$ $250 \mathrm{mOsM} ; \mathrm{pH}=7.4)$, washed overnight in $0.1 \mathrm{M}$ buffer, post-fixed in $2 \%$ osmium tetroxide at room temperature for $1 \mathrm{~h}$ and embedded in ERL 4206 (Spurr, 1969). Ultrathin sections were stained with uranyl acetate and lead citrate (Reynolds, 1963).

Demonstration of extracellular spaces and endocytotic phenomena. - Ovotestes were incubated in a $5 \%$ horseradish peroxidase Tyrode solution for $30 \mathrm{~min}$ to $18 \mathrm{~h}$. After fixation in $2 \%$ cacodylate-buffered glutaraldehyde $(\mathrm{pH}=7.4)$ the tracer was revealed by incubating the pieces for $30 \mathrm{~min}$ in a medium using 3-3' diaminobenzidine as substrate (Graham and Karnovsky, 1966). The tissues were then post-fixed in $2 \%$ osmium tetroxide and routinely prepared for electron microscopy. The ultrathin sections were not stained.

Polysaccharide detection. - The periodic acid-thiosemicarbazide-silver proteinate (PATAg) reaction (Thiéry, 1967) was used to indicate polysaccharide components with vicinal glycols. The sections were exposed to thiosemicarbazide for $40 \mathrm{~min}$ (glycogen) or $72 \mathrm{~h}$ (glycoproteins).

Light microscopy. - Semi-thin sections were stained with toluidine blue (Trump et al., 1961) or PAS-toluidine blue.

For cytochemical studies, the ovotestes were fixed in Bouin-Hollande or Carnoy liquids and embedded in paraplast. The techniques were carried out according to the recommendations of Gabe (1968). The following tests were used : Mann-Dominici for cytoplasm basophilia, PAS and alcian blue for revealing polysaccharide components, alizarin sodium sulfonate for the calcium, gallocyanin and pyronin-methylgreen for the nucleic acids and Feulgen for DNA. As a control, the Brachet and trichloracetic acid tests were used for the nucleic acids and digestion by a protease (type 1 , Sigma $\left(^{2}\right)$ for the proteins.

\section{Results.}

As in other pulmonate gastropods, the ovotestis of adult Helix aspersa is composed of a large number of tubules (acini) connected with the hermaphroditic duct. These tubules contain male and female cells. The cells of the female germ line are localized inside the "germinal epithelium " lining the acini. The youngest female cells are located in the proximal part of each acinus, whereas the larger ones complete differentiation at the bottom (fig. 1). The development of these cells has been subdivided into six stages (summarized in table 1) according to size, cytological, cytochemical and ultrastructural characters and to their relationship with the neighbouring cells.

\section{Structural observations.}

Oogonia. - Although often isolated, the oogonia can constitute clusters of 2 to 4 cells, incompletely separated from each other due to extensions of the adjoining epithelial cells (fig. 1, PI. II). At the ultrastructural level (fig. 1, PI. II),

(2) Sigma Chemical Co., USA. 


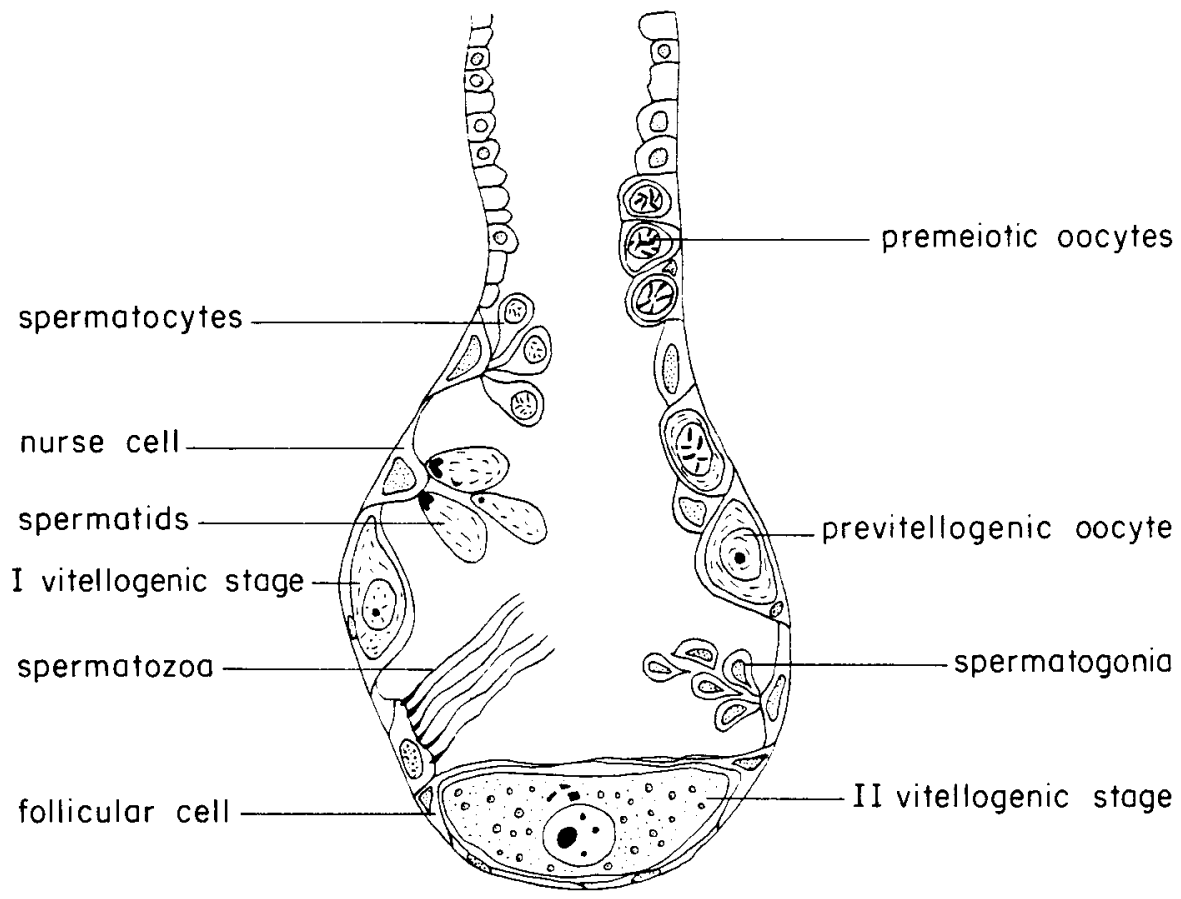

FIG. 1. Longitudinal section through an acinus.

they are recognizable by a weakly contrasted cytoplasm and an heteromorphic, more or less elongated profile. The nucleus, irregular in outline, possesses one nucleolus and small clusters of heterochromatin. Several Golgi bodies and round mitochondria with a clear matrix are scattered in the cytoplasm. The rough endoplasmic reticulum (RER) is abundant and organized into concentric whorls around the nucleus.

Young oocytes. - Before premeiosis starts, the oocyte and its nucleus become round.

Premeiotic stage. - At the beginning of this phase, the oocytes may still be adjacent but neighbouring epithelial cells with dark nuclei and glycogen rosettes insinuate extensions to isolate them from each other and also from the acinar lumen. They gradually constitute a follicular envelope. Each oocyte, however, remains in contact with the basal lamina (fig. 2, PI. II). In the enlarging nucleus, the stages of meiotic prophase (fig. 1, PI. I) are visible until the pachytene stage, after which chromatin decondensation begins. One or two nucleoli have eccentric positions and may be adjacent to the nuclear envelope. In the slightly basophilic cytoplasm, the RER is fragmented in short cisternae, ribosomes are abundant and a few heterogeneous inclusions are sometimes visible. The oocyte becomes progressively oval-shaped.

Reproduction, Nutrition, Développement $n^{\circ} 2$ A-1986. -6 


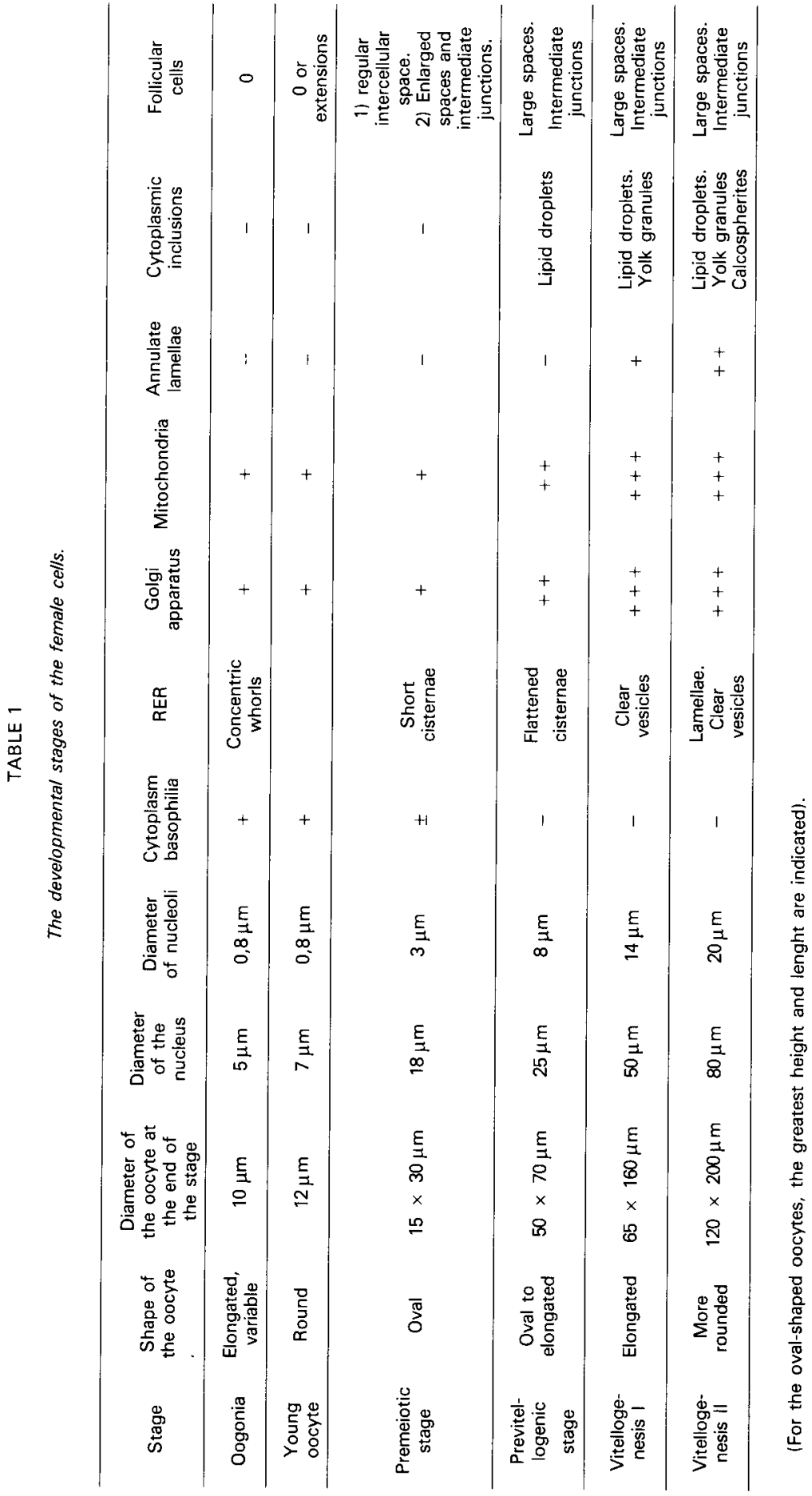


Previtellogenic stage. - This stage is characterized by a considerable increase in oocyte and nuclear volume. The long axis of the oocyte is generally oriented parallel to the acinar wall (fig. 2, PI. 1). The cytoplasm loses the basophilia. The number of mitochondria as well as of dictysomes strongly increases ; the RER forms flattened cisternae (fig. 1, PI. III). Lipid droplets occur in clusters usually located at both extremities of the cell. The use of horseradish peroxidase shows a few endocytotic figures.

The decondensation of the chromatin continues inside the germinal vesicle and some aggregations of light material radiating around the single nucleolus are visible. At the end of this stage, one or two spherical buds may be seen at the nucleolar periphery.

At the apical and lateral sides of the oocyte, the intercellular spaces are regular at first ; they then enlarge and some intermediate junctions connect the oocyte to the follicular cells.

First vitellogenic stage. - In the germinal vesicle (fig. 3, PI. I) the chromatin is no longer visible; the nucleolus enlarges, and it is common to find some buds annexed to it (fig. 2, PI. III) ; 7 to 10 nucleolus-like bodies may coexist in a section. Several spheres of weakly contrasted fibrillar material are also observed in the nucleoplasm (fig. 3, PI. III) or adjacent to the nuclear envelope (fig. 4, PI. III) which is riddled with pores (fig. 5, PI. III).

The cytoplasm is filled with clear vesicles (fig. 6, PI. III) which probably originate from the RER because their surface bears some ribosomes. Elongated mitochondria with a dense matrix and few cristae are very numerous especially at the extremities of the oocyte. Prominent saucer-shaped dictysomes (fig. 7, PI. III) pinch off a multitude of vesicles. Some lysosomes, multivesicular bodies and the first yolk granules appear; these are spherical with an homogeneous, electrondense content.

The intercellular spaces gradually enlarge between the follicle cells and the oocytes which remain in contact in small areas, usually differentiated into intermediate junctions (fig. 8 , PI. III). Horseradish peroxidase reveals some small or large pinocytotic vacuoles, although these are not very numerous after $18 \mathrm{~h}$ of incubation.

Second vitellogenic stage. - The nucleolus, nucleolus-like bodies and fibrillar spheres enlarge (fig. 4, PI. I). At the ultrastructural level, clear spots are visible in the nucleolus.

Some annulate lamellae differentiate, especially during the second phase of vitellogenesis. They appear close to the nuclear envelope or are connected with RER lamellae (fig. 1, PI. IV.). In light microscopy sections, they form a group of rods between the nuclear and the plasma membranes next to the acinar lumen (fig. 5, PI. I).

Outside this area, the cytoplasm is crowded with various organelles and inclusions (fig. 2, PI. IV), i.e. dark elongated mitochondria, lipid droplets, clear vesicles, RER lamellae encircling cellular areas, Golgi and multivesicular bodies. The dictyosomes pinching off a large quantity of vesicles may give rise to 

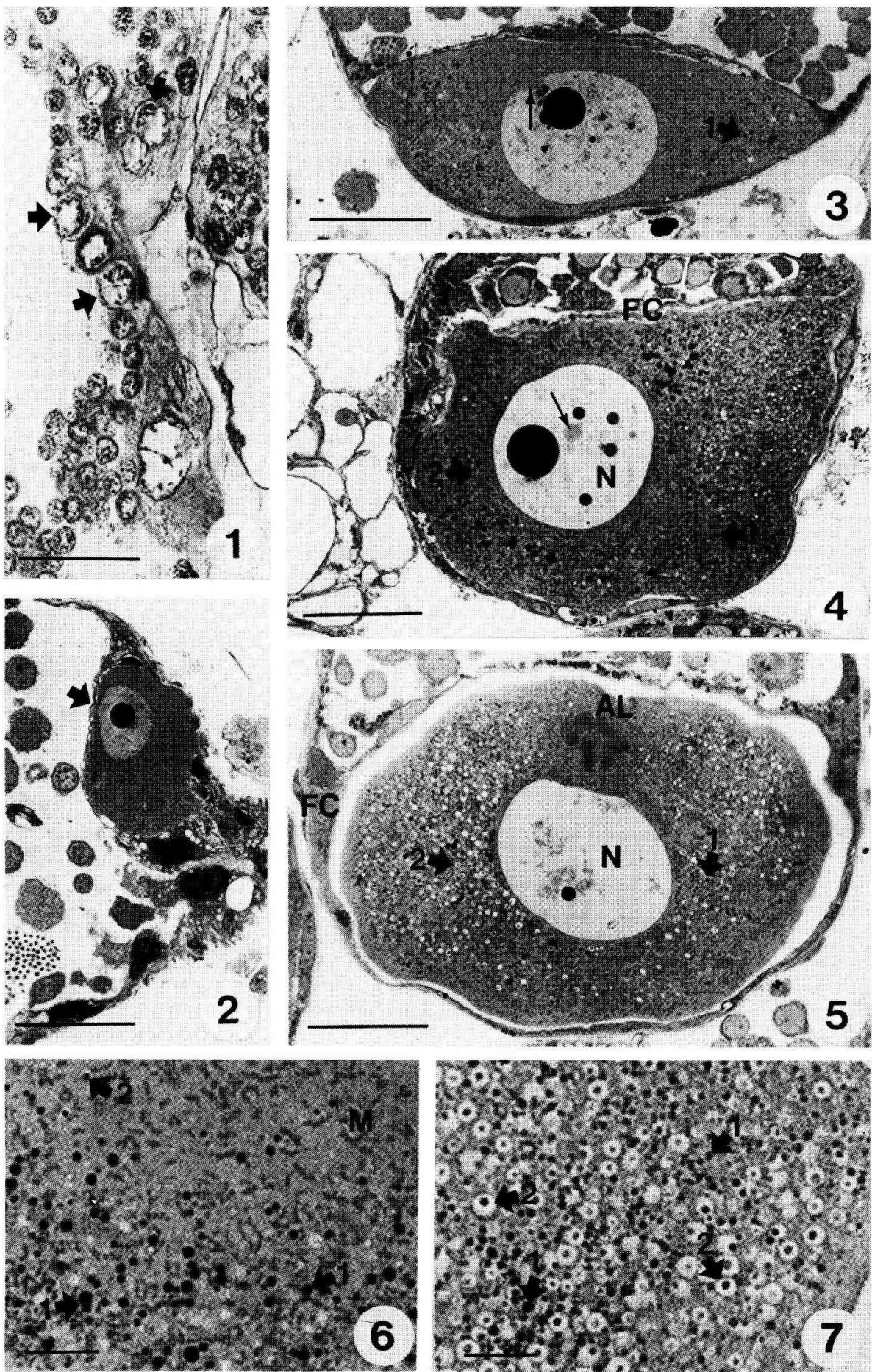

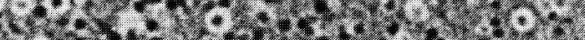

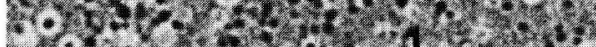

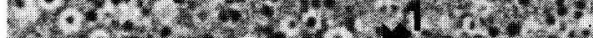

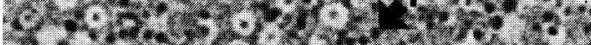

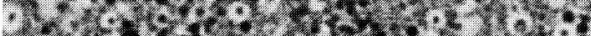

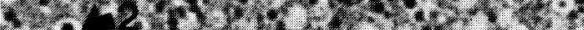

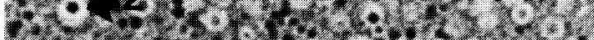

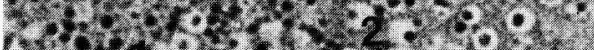

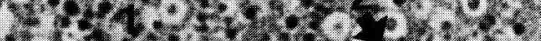

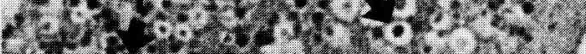

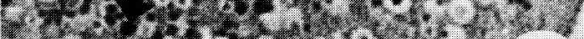
( Hos 
multivesicular bodies which become more and more dense and seem to be at the origin of the homogeneous yolk granules (fig. 4, PI. IV). In addition to yolk, a second type of inclusion consists of voluminous vesicles containing a core composed of several concentric rings of more or less dense material (figs. 2 and 3 , PI. IV). These inclusions seem to originate from the clear vesicles described at the preceding stage, but sometimes the innermost saccule of the maturing face and the extremities of the following saccules of numerous dictysomes dilate into voluminous vesicles in which rings of dense material concentrate (fig. 5, PI. IV).

As in the preceding stages, the use of horseradish peroxidase during this second phase of vitellogenesis shows the presence of endocytotic vesicles in the peripheral area of the oocyte (figs. 6 and 7, PI. IV), but tracer uptake into the oocyte is never extensive. At the end of oogenesis, the nuclear envelope is folded; yolk bodies and inclusions with a dense core are dispersed over the whole cytoplasm without any stratification. A large cleft forms around the oocyte, the plasma membrane of which has developed microvilli, but some contact areas of the oocyte and its surrounding follicle cells are still visible (fig. 8, PI. IV).

\title{
II. Cytochemical observations.
}

Nucleolar changes. - During the early stages of oogenesis, the nucleoli are intensively stained by gallocyanin and pyronin. As vitellogenesis proceeds, the single nucleolus enlarges and gradually loses the color of the stain used for nucleic acids. However, it conserves a pyroninophilic cap which indicates the segregation of nucleolar material.

\author{
PLATE I \\ Changes in the shape and size of the oocytes, nuclei, nucleoli and \\ nucleolus-like bodies during oogenesis. \\ (Stained with toluidine blue) Bars $-40 \mu \mathrm{m}$ ) $\times 400$.
}

FIG. 1. - Premeiotic oocytes (thick arrows): the chromosomes are visible in the nucleus.

FIG. 2 - Previtellogenic stage. The oocyte (thick arrow) has enlarged. The clear germinal vesicle contains an unique nucleolus.

FIG. 3. - First vitellogenic stage. A large nucleolus, some nucleolus-like bodies and weakly contrasted material (thin arrow) are seen in the germinal vesicle. Note the presence of yolk granules (arrow 1 ) in the cytoplasm.

FIG. 4. - Beginning of the second vitellogenic stage: the yolk granules are numerous (arrow 1). The first mineral spherites (arrow 2) appear in the cytoplasm. FC : follicular cell ; thin arrow : weakly contrasted material.

FIG. 5. - End of the second vitellogenic stage. The cytoplasm is filled with yolk bodies (arrow 1) and mineral spherites (arrow 2). AL : annulate lamellae; FC : follicular cell.

FIG. 6. - Detail of the cytoplasm of an oocyte at the beginnig of the second vitellogenic stage. M : mitochondria ; arrow 1 : yolk ; arrow 2: mineral spherite. (Bar $-10 \mu \mathrm{m}) \times 1000$.

FIG. 7. - Detail of the cytoplasm of an oocyte at the end of the second vitellogenic stage. Arrow 1 : yolk; arrow 2 : mineral spherite. (Bar $-10 \mu \mathrm{m}) \times 1000$. 


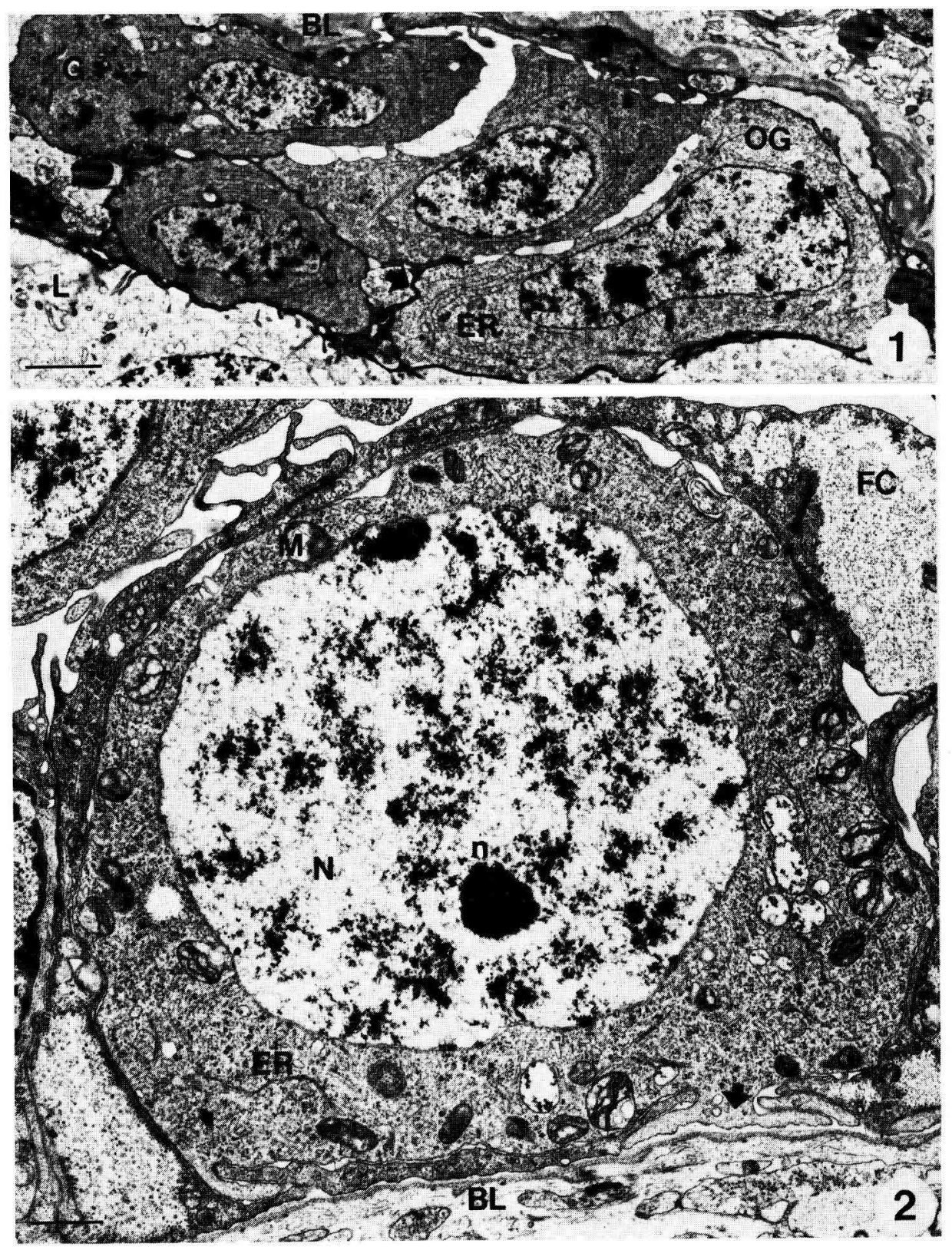

PLATE II

FIG. 1. - Cluster of oogonia (OG).

$\mathrm{BL}$ : basal lamina ; ER : RER ; G : Golgi apparatus : $L$ : acinar lumen ; arrow : extensions of neighbouring epithelial cells ; (Bar $-2 \mu \mathrm{m}$ ) $\times 4700$.

FIG. 2. - Premeiotic oocyte. The arrow indicates a contact zone between the oocyte and the basal lamina (BL).

ER : RER ; FC : follicular cell ; $M$ : mitochondria ; $N$ : nucleus ; $n$ : nucleolus (Bar $-1 \mu \mathrm{m}$ ) $\times 9300$. 
The nucleolus-like bodies are very pale or uncolored after treatment for the identification of the nucleic acids and do not respond to Brachet's or trichloracetic acid tests. They are still visible after 7 to $10 \mathrm{~h}$ of protease digestion.

Inclusion components. - Yolk granules are PAS-positive but alcian bluenegative. On the other hand, with the PATAg reaction, only rare glycogen rosettes are dispersed throughout the cytoplasm, especially around the lipid droplets. No silver particles are visible on the yolk, even after $72 \mathrm{~h}$ in thiosemicarbazide (fig. 9, PI. IV). The use of protease makes the yolk granules partially disappear.

The centralmost part of the core of the second type of inclusion is sometimes PAS-positive; the most peripheral layers are very refringent and stain red by alizarin sodium sulfonate, revealing the presence of calcium.

\section{Discussion and conclusion.}

As reviewed by Dohmen (1983), oogenesis in molluscs may be divided into three stages. The present descriptive study distinguishes six different stages in Helix aspersa oogenesis.

1. Oogonia have rarely been described in hermaphroditic molluscs. Apart from the small size of $H$. aspersa oogonia, they may be recognized at the ultrastructural level by concentric, well developed RER lamellae. Neither the nongerm cells nor the mother spermatogonia display a similar RER arrangement.

2. Prior to premeiosis, the female cells enlarge and become round.

3. During the premeiotic stage (according to Raven's terminology, 1961), the chromosomes undergo typical prophase changes during the first maturation division.

4. Because the appearance of yolk substances is a continuous process in Helix as in other gastropods (Bottke, 1974 ; de Jong-Brink et al., 1976), several criteria must be considered simultaneously to determine the developmental stage of an oocyte. During previtellogenesis the major events are oocyte growth, chromatin dispersion in the germinal vesicle, and the appearance of lipid droplets.

5. The first vitellogenic stage is characterized by considerable nucleolar activity and the accumulation of yolk granules.

6. At the second vitellogenic stage, the annulate lamellae and inclusions centered around a dense mineral core differentiate.

$H$. aspersa oocytes present some particularities compared to other gastropod species (Favard and Carasso, 1958 ; Terakado, 1974 ; de Jong-Brink et al., 1976 ; Hill and Bowen, 1976 ; Griffond, 1980). The yolk bodies are homogeneous granules; they never have the aspect of platelets or contain crystalline or membranous material. Our cytochemical observations suggest that the yolk consists of proteins associated to neutral polysaccharide components. (The negative results obtained with the PATAg reaction may be due to the nature of the fixative or of the resin). The presence of mineral spherites in oocytes is unusual and suggests the storage of inorganic ions, presumably destined for 


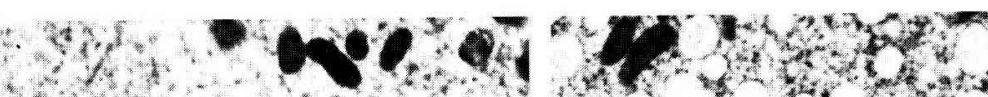
6.

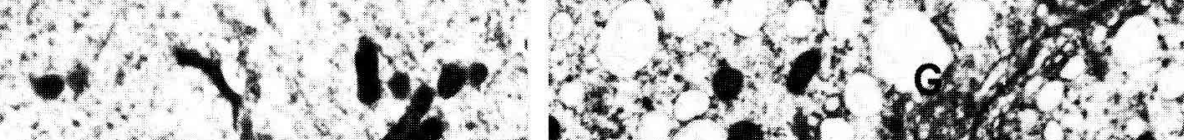

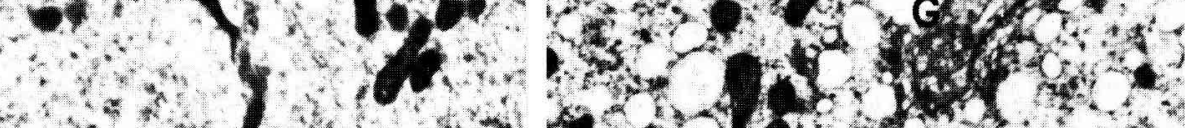

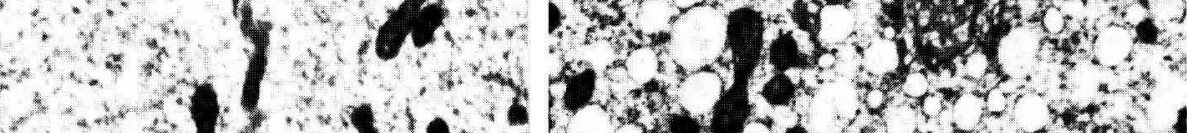
to 10.1964 6). - .

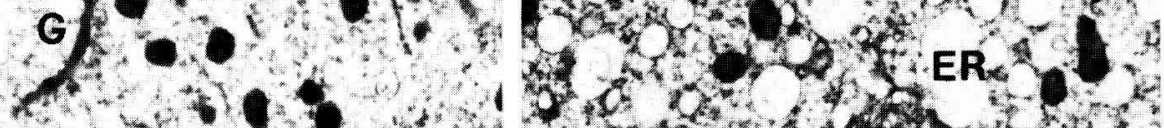
$4,40+6401,10$

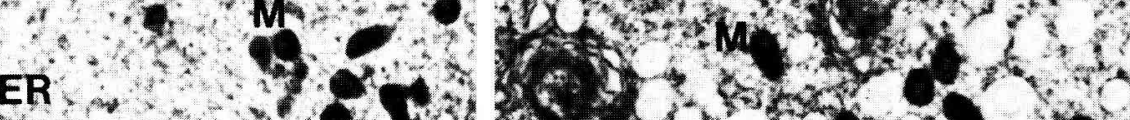

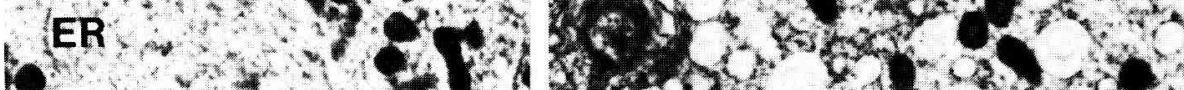

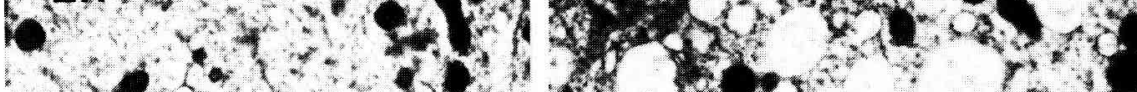

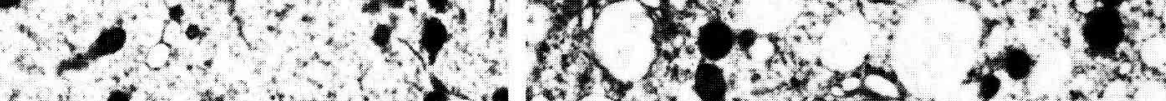

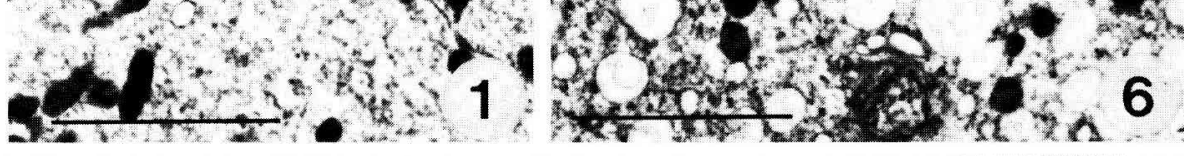
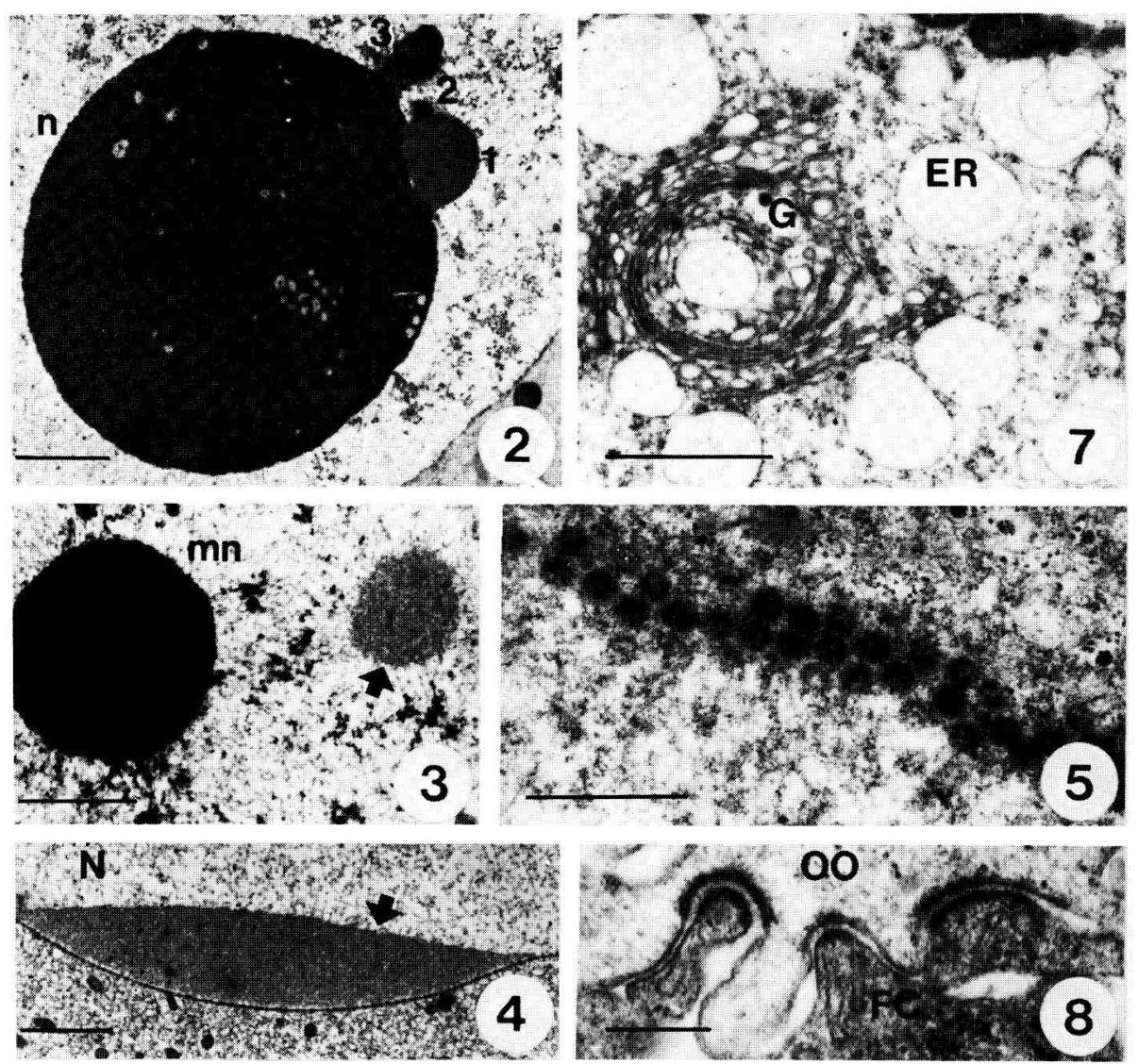
embryo shell formation. According to McGee-Russell (1968), the vesicles in which calcification occurs are the product of a specialized activity of the endoplasmic reticulum; no direct association between the Golgi apparatus and the vesicles was seen. On the contrary, we sometimes observed the enlargement and transformation of Golgi saccules, a process also described in two other glands of the genital tract of the same animal, the multifid gland (Ovtracht and Thiéry, 1978) and the prostate gland (Enée and Gomot, 1984).

We had to elucidate the normal physiology of the female cells of $H$. aspersa in order to interpret their evolution under experimental conditions. This study points out some interesting aspects which merit investigation, such as the nature and functional significance of nucleolus-like bodies and of weakly contrasted fibrillar nuclear material, and the origin of the yolk. Using labelled carbohydrate and amino acid precursors, we are currently trying to determine the ways in which the Golgi apparatus, and probably the RER, participates in the development of the endogenous yolk. The use of horseradish peroxidase demonstrates some endocytotic phenomena, but the problem of exogenous protein incorporation from the hemolymph into the oocytes is not clear; the importance of this process in $H$. aspersa oogenesis remains to be determined as well as the putative participation of the follicle cells in the synthesis of oocyte reserves.

Reçu en septembre 1985.

Accepté en novembre 1985.

Acknowledgements. - The authors wish to thank Miss B. Jolibois for technical assistance and $\mathrm{Mr} \mathrm{A}$. Martin for printing the photographs.

PLATE III

FIG. 1. - Cytoplasm of a previtel/ogenic oocyte. ER : RER ; G : Golgi apparatus ; $M$ : mitochondria ; Bar $-3 \mu \mathrm{m}) \times 7,000$.

FIGS. 2-8. - Details of an oocyte at the first vitellogenic stage.

FIG. 2. - Some buds $(1,2,3)$ are annexed to the nucleolus $(\mathrm{n})$. (Bar $-2 \mu \mathrm{m}) \times 4,700$.

FIGS. 3-4. - Weak/y contrasted material (arrows) is seen in the nucleoplasm $(\times 6,000)$ or against the nuclear envelope $\times 4,000)$. $\mathrm{mn}$ : nucleolus-like body: $\mathrm{N}$ : nucleus ; (Bar $-2 \mu \mathrm{m})$.

FIG. 5. - Pores of the nuclear envelope. (Bar $-0,5 \mu \mathrm{m}) \times 32,700$.

FIG. 6. - Aspect of the cytoplasm. ER : vesicles of the endoplasmic reticulum ; $G$ : Golgi apparatus ; $\mathrm{M}$ : mitochondria ; (Bar - $3 \mu \mathrm{m}) \times 7,000$.

FIG. 7. - Dictyosome (G) and vesicles of the endoplasmic reticulum (ER). (Bar $-1 \mu \mathrm{m}) \times 18,000$. FIG. 8. - Intermediate junctions between an oocyte (OO) and a follicular cell (FC). (Bar - 0,25 $\mu \mathrm{m}$ ) $\times 42,000$. 


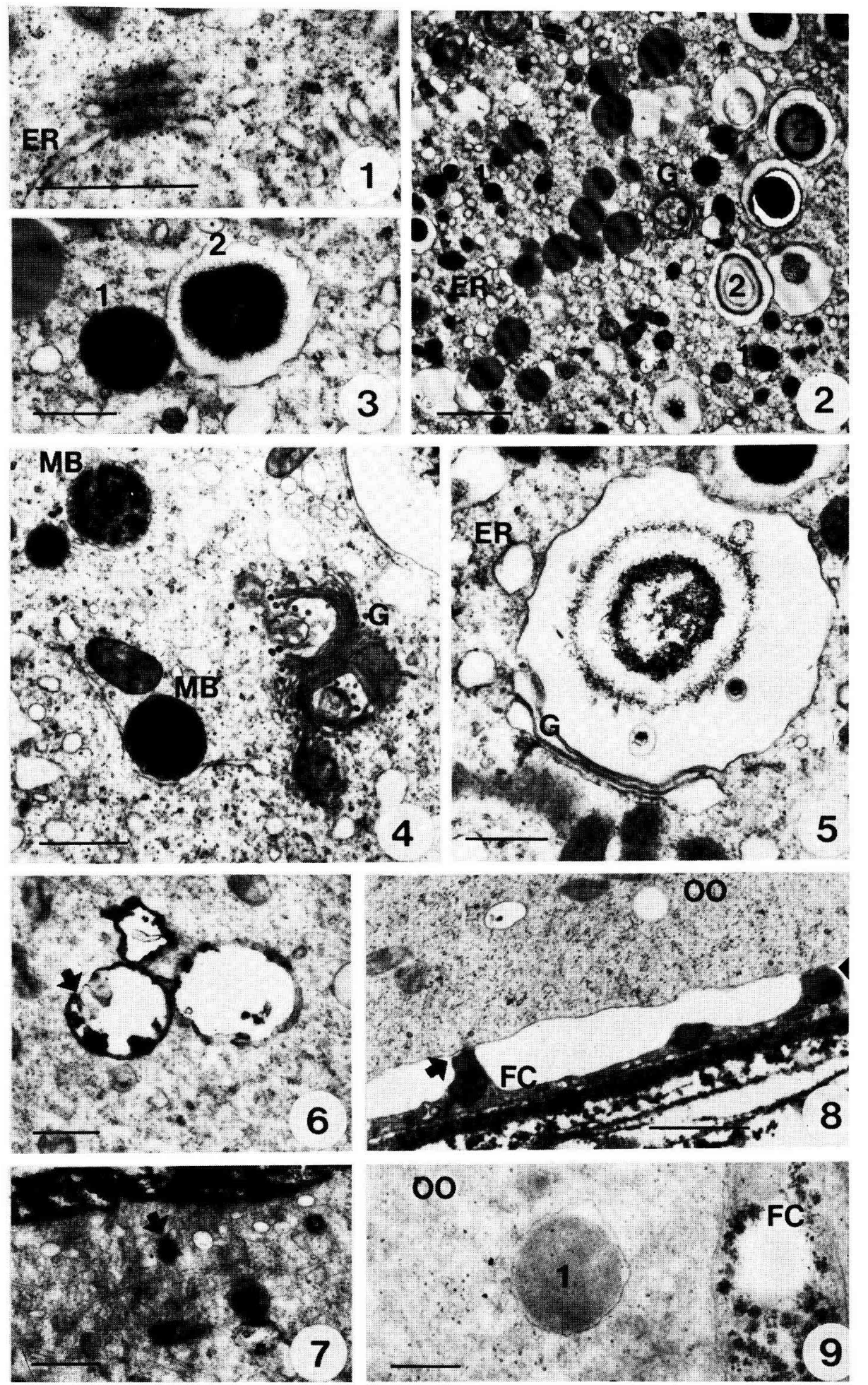


Résumé. Les stades de l'ovogenèse de l'Escargot Helix aspersa : étude cytologique, cytochimique et ultrastructurale.

Le déroulement de l'ovogenèse a été étudié chez des Escargots Helix aspersa adultes, en microscopie photonique et électronique. Sur la base de critères morphologiques, cytochimiques et ultrastructuraux, nous avons distingué six stades au cours desquels nous précisons la taille des cellules, l'abondance et la localisation des organites cytoplasmiques, l'évolution du noyau et du nucléole, la chronologie d'apparition des substances de réserves et les relations structurales ovocytes-cellules folliculaires.

\section{References}

BOTTKE W., 1974. The fine structure of the ovarian follicle of Alloteuthis subulata Lam. (Mollusca, Cephalopoda). Cell Tiss. Res., 150, 463-479.

DOHMEN M. R., 1983. Gametogenesis, 1-48. In VERDONK N.H., Van den, BIGGELAAR J. A. M., TOMPA A. S., Mollusca, vol. 3, Development, Acad. Press, New York.

ENÉE J., GOMOT L., 1984. Organogenèse et cytodifférenciation de la prostate de l'Escargot Helix aspersa Müller. Reprod. Nutr. Dév., 24, 563-585.

FAVARD P., CARASSO N., 1958. Origine et ultrastructure des plaquettes vitellines de la Planorbe. Arch. Anat. micr. Morph. exp., 47, 211-234.

GABE M., 1968. Techniques histologiques, Masson et Cie, Paris.

GRIFFOND B., 1980. La vitellogenèse chez la Paludine Viviparus viviparus L. (Mollusque Gastéropode Prosobranche). Bull. Soc. Zool. Fr., 105, 401-407.

GRAHAM R. C., KARNOVSKY M. J., 1966. The early stages of absorption of injected horseradish peroxidase in the proximal tubules of mouse kidney; ultrastructural cytochemistry by a new technique. J. Histochem. Cytochem., 14, 291-302.

GUYARD A., 1971. Etude de la différenciation de l'ovotestis et des facteurs contrôlant l'orientation sexuelle des gonocytes de l'Escargot Helix aspersa Müller. Th. Doct. Sci. nat., Besançon, $\mathrm{n}^{\circ} \mathbf{5 6}$.

HILL R. S., BOWEN I. D., 1976. Studies on the ovotestis of the slug Agriolimax reticulatus (Müller). I. The oocyte. Cell Tiss. Res., 173, 465-482.

JONG-BRINK M. de, WIT A. de, KRAAL G., BOER H. H., 1976. A light and electron microscope study on oogenesis in the freshwater pulmonate snail Biomphalaria glabrata. Cell Tiss. Res., 171, 195-219.

\section{PLATE IV}

Details in an oocyte at the second vitellogenic stage.

FIG. 1. - Annulate lamellae in relation to the RER (ER). (Bar $-1 \mu \mathrm{m}$ ) $\times 23,000$.

FIG. 2. - Aspect of the cytoplasm. ER : RER ; G: Golgi apparatus ; L : lipid globule ; 1 : yolk bodies ; 2 : mineral spherites ; (Bar $-2 \mu \mathrm{m}) \times 5,300$.

FIG. 3. - Yolk body (1) and mineral spherite (2). (Bar $-1 \mu \mathrm{m}) \times 12,000$.

FIG. 4. - Saucer-shaped dictyosomes (G) and multivesicular bodies (MB) are very numerous. (Bar $1 \mu . \mathrm{m}\rangle \times 12,000$.

FIG. 5. - Formation of mineral spherite. ER : RER ; G : Golgi apparatus ; (Bar $-0,5 \mu \mathrm{m}) \times 21,000$. FIG. 6, 7. - Incubation in horseradish peroxidase: some large and small endocytotic vesicles (arrows) are shown. (Bar $-0,5 \mu \mathrm{m}) \times 18,000$.

FIG. 8. - Small contact areas (arrows) between a follicular cell (FC) and an oocyte (OO). (Bar $1 \mu \mathrm{m}) \times 14,000$.

FIG. 9. - PATAg reaction : no silver particles are detected on yolk granules (1) whereas glycogen rosettes are visible in a follicular cell (FC). 00 : oocyte ; $(B a r-0,5 \mu \mathrm{m}) \times 20,000$. 
McGEE-RUSSELL S. M., 1968. The method of combined observations with light and electron microscopes applied to the study of histochemical colourations in nerve cells and oocytes, 183-207. In McGEE-RUSSELL S. M., ROSS K. F. A., Cell structure and its interpretation. Arnold, London.

OVTRACHT L., THIÉRY J. P., 1978. Différenciation zonale et transformation du saccule golgien issu de la face de maturation (sac post-golgien). Biol. cell., 32, 191-202.

RANZOLI F., 1957. Osservazioni sull' ovogenesi di Helix lucorum e sui rapporti fra gametogenesi maschile o femminile e cellule nutrici. Boll. Zool. Ital., 24, 1-8.

RAVEN C. P., 1961. Oogenesis. The storage of development information. Pergamon Press, Oxford, London, Paris.

REYNOLDS E. S., 1963. The use lead citrate at high $\mathrm{pH}$ as an electron opaque stain in electron microscopy. J. Cell Biol., 17, 208-212.

ROGERS BRAMBELL F. W., 1924. The nature and origin of yolk. Experimental studies of the oocytes of Helix aspersa and Patella vulgata. Brit. J. exp. Biol., 1, 501-507.

SERRA J. A., QUEIROZ LOPEZ A., 1945. Données pour une cytophysiologie du nucléole. 1. L'activité nucléolaire pendant la croissance de l'ovocyte chez les Helicidae. Portug. Acta biol. 1. 51-91.

SPURR A. R., 1969. A low-viscosity epoxy resin embedding medium for electron microscopy. J. Ultrastruct. Res., 26, 31-43.

TERAKADO K., 1974. Origin of yolk granules and their development in the snail Physa acuta. J. Electron Micr., 23, 99-106.

THIÉRY J. P., 1967. Mise en évidence des polysaccharides sur coupes fines en microscopie électronique. J. Microscopie, 6, 987-1018.

TRUMP B. F., SMUCKLER E. A., BENDITT E. P., 1961. A method for staining epoxy sections for light microscopy. J. Ultrastruct. Res., 5, 343-345.

VINCENT C., GRIFFOND B., GOMOT L., BRIDE J., 1984. Etude in vitro de l'influence des corps dorsaux sur l'ovogenèse d'Helix aspersa Müll. Gen. Comp. Endocrinol., 54, 230-235. 